\title{
Application of Finite Strain Technique for Deformed Lithologies in Al Amar Suture, Eastern Arabian Shield
}

\author{
Osama M. K. Kassem ${ }^{*}, 1,2$ and Zakaria Hamimi ${ }^{3,4}$ \\ ${ }^{1}$ SGSRC, Department of Geology, Faculty of Science, King Saud University, P.O. Box 2455, Riyadh 11451, Saudi \\ Arabia \\ ${ }^{2}$ Geology Department, National Research Center, Al-Behoos str., 12622 Dokki, Cairo, Egypt \\ ${ }^{3}$ Department of Structural Geology and Remote Sensing, Faculty of Earth Sciences, King Abdulaziz University, P.O. Box \\ 80206, Jeddah 21589, Saudi Arabia \\ ${ }^{4}$ Geology Department, Faculty of Science, Banha University, Banha, Egypt
}

\begin{abstract}
Finite strain technique was applied for Abt schist, sheared granitoids and volcanosedimentary rocks exposed at Al Amar area, eastern Arabian Shield, in an attempt to decipher the relationship of these lithologies to nappe contacts and to clarify the nature of subhorizontal foliation pervasively recorded in the area. The $\mathrm{R}_{\mathrm{f}} / \varphi$ and Fry methods were utilized on quartz and feldspar porphyroclasts, as well as on mafic crystals, such as hornblende and biotite, in eighteen samples. The $\mathrm{X} / \mathrm{Z}$ axial ratios ranged from 1.12 to 4.99 for $\mathrm{R}_{\mathrm{f}} / \varphi$ method and from 1.65 to 4.00 for Fry method. The direction of finite strain for the long axes displayed clustering along the WNW trend (occasionally $\mathrm{N}$ ) with slight plunging. The $\mathrm{Z}$ axes were subvertical and associated with a subhorizontal foliation. The data revealed oblate strain symmetry (flattening) and the strain magnitudes showed no considerable increase towards the tectonic contacts. The obtained finite-strain data demonstrated that the sheared granitoids are mildly to moderately deformed. It is suggested that the accumulation of finite strain was not associated with any significant volume change. The penetrative subhorizontal foliation was concurrent with thrusting and showed nearly the same attitudes of tectonic contacts with the overlying nappes. Field relations and observations, together with finite stain data, are inconsistent with the proposed idea that nappes in orogens resulted from simple-shear deformation.
\end{abstract}

Keywords: Finite strain, Abt schist, Al Amar area, Arabian Shield, Saudi Arabia.

\section{INTRODUCTION}

The Arabian-Nubian Shield (ANS) includes Middle Cryogenian-Ediacaran (790-560 Ma) sedimentary and volcanic terrestrial and shallow-marine successions unconformable on juvenile Cryogenian crust [1]. ANS comprises the basement outcrops that are exposed on northeastern Africa (Nubian Shield) and western Arabia (Arabian Shield) because of the uplifting concurrent with Red Sea rifting since the Oligocene and younger ages [2]. [3] believed that the shield constitutes one of the largest best exposed tracts of juvenile Precambrian continental crust on the Earth and its history is intimately linked with a Neoproterozoic "Supercontinental Cycle" [4]. This cycle began with the rifting, break-up and fragmentation of Rodinian Supercontinent in the early Cryogenian [5], continued with the opening and closing of one or two oceanic basins [6,7], and ended with the convergence of fragments of East and West Gondwana and the formation of the new supercontinent of "Greater Gondwana" [6] or "Pannotia" [8]. [6] introduced the term "East African

*Address correspondence to this author at the SGSRC, Department of Geology, Faculty of Science, King Saud University, P.O. Box 2455, Riyadh 11451, Saudi Arabia; Tel: +966-14676351;

Fax: +966-14670729; E-mail: kassemo1@yahoo.com
Orogen" (EAO) to include deformed and metamorphosed rocks of the ANS in the north and higher grade and more strongly deformed rocks of East Africa and Madagascar in the south (Mozambique Belt, MB); the EAO was over 6000 $\mathrm{km}$ long in Gondwana [9]. These differ significantly in geodynamic setting with island arc accretion and major wrench tectonics in the ANS [6] and continental collision tectonics in the MB [10-14]. The "East African-Antarctic Orogen" (EAAO), proposed by [15] to represent the southern continuation of the EAO through Mozambique into Antarctica, was challenged by results obtained by [7]. The EAO is regarded as an extensive Neoproterozoic accretionary orogen and collisional zone within Gondwana $[6,16,17,18]$. Based on the obtained geochronologic age $(652 \pm 10 \mathrm{Ma})$ for zircons in garnet-bearing pyroxene granulite in Tanzania [19], it was realized that high-grade metamorphism in East Africa was a Neoproterozoic, not an older event, despite the Mesoproterozoic to Archaean protolith ages of some of the rocks caught up in the orogen [20]. [21] extended the MB northward into the ANS and [22] described ANS-type ophiolite-decorated north-trending shear zones extending south into central Kenya, confirming that the MB and the ANS are correlatives.

The determination of finite strain is one of the principal goals of structural geology. The magnitude and orientation of the finite strain ellipsoid are critical for constraining, for 
example, fold and fault mechanisms, displacement across ductile shear zones. Most strain measurement techniques $(\mathrm{Rf} / \phi$, center-to-center, Fry, etc.) return finite strain ratios which are useful for many applications [23-29]. However, there are some applications for which absolute finite strains are required. Measurement of absolute finite strains requires objects of known pre-deformation size whereas strain ratios may be determined if rocks contain objects of known shape or distribution. In this regard, the use of deformed rocks has been under-utilized as a strain measurement technique. In this paper, Al Amar area (Fig. 1) was studied as a contribution to the understanding of its structure and kinematic evolution. The study was achieved through field work and the interpretation of finite strain data. The main objective of the present work is to shed much light on the kinematic history Al Amar Suture juxtaposing Ad Dawadimi and Ar Rayn terranes (Fig. 1) in the extreme far east of the Arabian Shield. We applied finite strain technique on the deformed lithologies exposed in the area bounded by the latitude of Umm Ash Shalahib in the south and the latitude of Khnaiguiyah in the north in the extreme far east of the Arabian Shield. The study was achieved through field work, microstructural investigation and interpretation of finite strain data.



Fig. (1). Middle Cryogenian-Ediacaran sedimentary and volcanic assemblages in the ANS [20]. Ad Dawadimi and Ar Rayn terranes represent the Far East exposures of the ANS. 


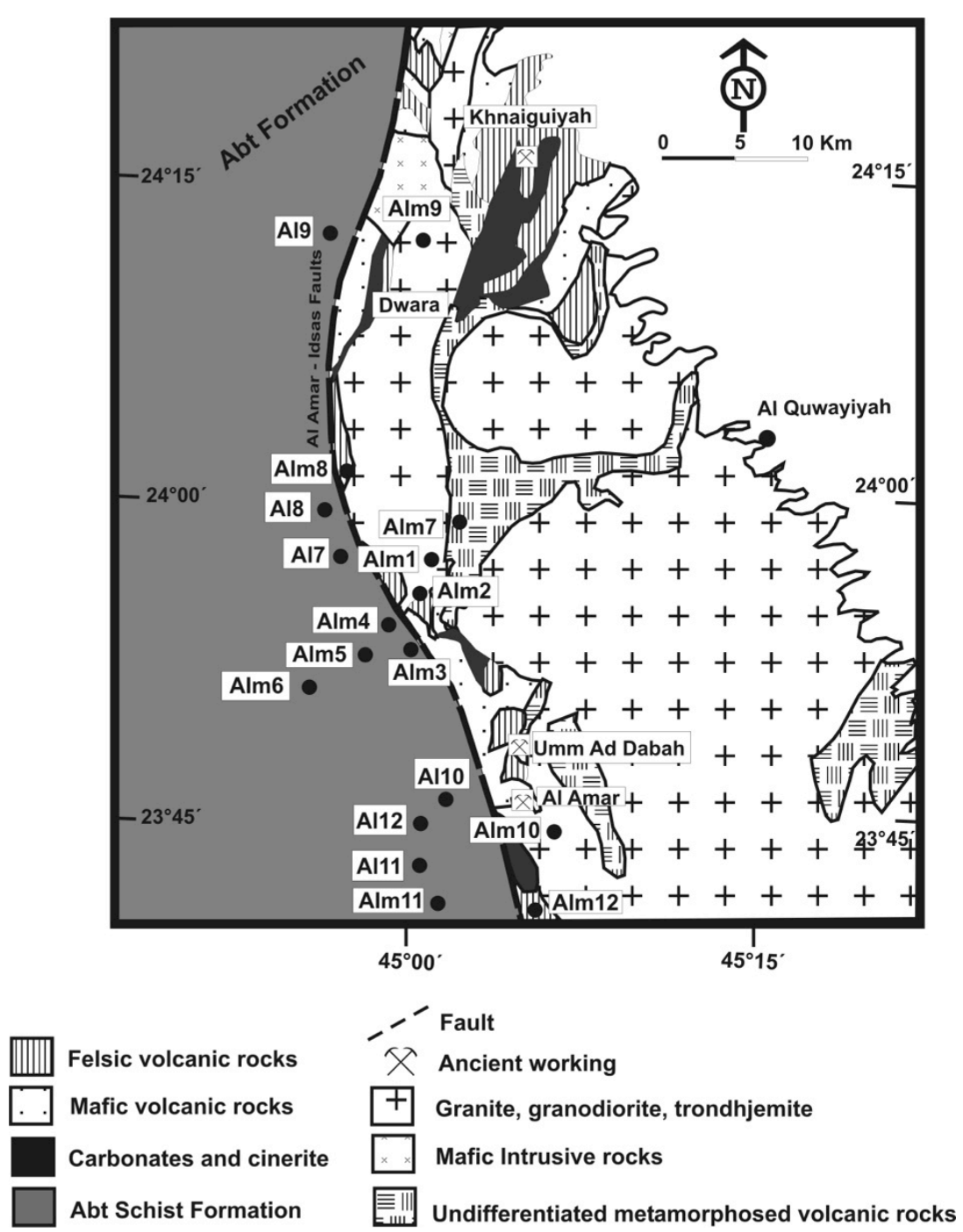

Fig. (2). Geological sketch map of Al Amar area and sample locations (modified after [32]).

\section{GENERAL GEOLOGY}

Three main lithologies are exposed in the area (Fig. 2) including Abt Formation, Al Amar Group and intrusive rocks. The Abt Formation is a low grade greenschist facies immature thick sedimentary unit, with $\mathrm{N}-\mathrm{S}$ strike, W-dipping foliation fabric and westward facing (younging direction). Unmappable marble bands are encountered within Abt Formation. Also, tight and intrafolial folds with N-S axial planes are observed highlighting the effect of, at least, two phases of deformation; the foliation is related to the older $D_{1}$ and the folds formed during the subsequent $\mathrm{D}_{2}$ phase. Petrographically, this formation comprises muscovitebiotite-quartz-feldspar schist, and feldspathic and volcanic metagraywackes. It covers vast domain in Ad Dawadimi terrane which contains also voluminous granites (syenogranite and alkali-feldspar granites) and layered gabbro, together with ophiolite mélange zones with forearc affinity. The combination of the immature sediments with forearc lithologies led [9] to conclude that Ad Dawadimi terrane has many similarities with more modern accretionary environments such as the Franciscan Formation of the western United States [30, 31]. Al Amar Group represents one of the main lithologies cropping out at Ar Rayn terrane.
It embraces continental-margin volcanic arc including westward dipping volcanosedimentary sequence (intermediate to silicic in composition) and related volcaniclastics. Throughout the whole Ar Rayn terrane, Amar Group is subdivided into about seven N-trending elongated belts because of the effect of tectonism and magmatism. It is intruded by syn- and post-tectonic intrusive rocks (667-580 Ma) encompassing gabbros and remarkably sheared granitoids (granite, granodiorite, tonalite and trondhjemite). Andesitic and rhyolitic flows, paragneisses and limestone are recognized in this group. Discrete contact metamorphism is detected near the contact of the volcanosedimentary sequence against the intrusives, particularly granitoids. Numerous NE-SW-trending listric normal faults are encountered in the study area and further north and south. The faults are too small to be mapped and dissect the area into tilted blocks.

\section{AL AMAR SUTURE ZONE}

The mapped area (Fig. 1) lies along the contact between Ad Dawadimi and Ar Rayn terranes which are believed to be the youngest terranes in the ANS among all, as will be dealt with later. Both Ad Dawadimi and Ar Rayn terranes are in 
direct juxtaposition along Al Amar Fault Zone which is known in previous literature as Al Amar-Idsas Fault Zone. Al Amar Fault is a westward steeply dipping N-trending shear zone extending over $\approx 200 \mathrm{~km}$ long, with $0.5-4 \mathrm{~km}$ average width. Because of the presence of relatively smallsized lensoidal blocks and fragments of ophiolites and carbonate-altered ultramafic rock (listwaenite and fuchsitetalc schist), this structure is considered by [33], and [34] as a suture zone; namely Al Amar Suture Zone. It is worthy to mention here that ophiolitic components are not encountered in the mapped area.

Elongated marble outcrops with discrete mineralized quartz veins (pyrite, calcite, fluorite and copper mineralizations) can be seen together along the suture zone [32]. The timing of suturing, trajectory of convergence and sense of shear along Al Amar Suture Zone are debatable. [20] pointed out the unknown sense of convergence and suggested a dextral horizontal slip based on the S-C shear fabrics that are restrictedly observed in few outcrops. They proposed $620 \mathrm{Ma}$ and $616 \mathrm{Ma}$ as ages of deformationmetamorphism and uplifting, respectively, for both Abt Formation and Al Amar Group depending upon the 607-565 Ma emplacement age for post-tectonic granites that intrude both Ad Dawadimi and Ar Rayn terranes. Within the frame of these previously mentioned ages, [20] inferred a suturing age of 620-605 Ma and considered Al Amar Fault as the youngest suture in the ANS, largely simultaneously with the Keraf Suture in the Nubian Shield, and also contemporary with the youngest shearing on the Najd Fault System. In the present study, shear sense indicators and other conclusive field evidence supporting the proposed dextral horizontal slip along Al Amar Fault are not encountered at the outcropscale. At the microscopic-scale, shear fabrics recorded in the investigated oriented thin sections (Fig. 3) indicate both dextral and sinistral movements, and make it difficult to deduct the overall sense of movement precisely along this conspicuous structural element in the far eastern side of the ANS.


Fig. (3). Microphotographs showing kinematic indicators along Al Amar Suture Zone; The elongated porphyroclasts and the fine crystals of the matrix reflecting both dextral ( $3 \mathrm{f}, \mathrm{h})$ and sinistral $(3 \mathrm{~b}, \mathrm{~d}, \mathrm{e}, \mathrm{g})$ movements 


\section{TECHNIQUES AND SAMPLING}

To quantify the finite strain for the Abt schist, sheared granitoids and volcanosedimentary rocks exposed in the mapped area, feldspar and quartz crystals and porphyroclasts, as well as mafic crystals (e.g. hornblende and biotite) have been analyzed by the $R_{f} / \varphi$ and Fry techniques [35-37]. Our strain data measurements are carried out using THETA and FRY programs (described by [38]) for $\mathrm{R}_{\mathrm{f}} / \varphi$ and fry methods, respectively. Furthermore, we used RJH Strain Calculator 3.1 program to calculate and plot strain data using a variety of input parameters, simulated simple shear, pure shear, and general shear, and show all related parameters (http: $\|$ www.earth.uq.edu.au $\sim$ rodh $\backslash$ soft ware). For $\mathrm{R}_{\mathrm{f}} / \varphi$ analysis on feldspars, the long and short axes of up to 40 grains per section were measured and the mean aspect ratio for each section was calculated. [39] showed that the deformation and shape of the feldspars depend on metamorphic conditions. At very low metamorphic grade, feldspars deform mainly by brittle fracturing and cataclastic flow. Tectonic strains were determined from the chi-squared minima of the $R_{f} / \varphi$ analyses [38]. For Fry analysis, the central points of more than 100 feldspar cyrstals per section were used to calculate strain. The strain estimates were used to calculate the finite-strain ellipsoid according to the modified least-square technique of [40]. A total of eighteen samples were collected for the purpose of finite strain analyses during the field work (Fig. 2), eleven samples from Abt Schist, two samples from granodiorite, two samples from granite and three samples from the volcanosedimentary rocks. The Fry method was applied for all samples to compare with the $\mathrm{R}_{\mathrm{f}} / \varphi$ results. The feldspar, quartz and mafic crystals were marked and scanned, and the traced outlines were then digitized. A least squares best-fit ellipse was calculated for each marker outline, as well as its relative position and orientation.

\section{RESULT OF FINITE-STRAIN ANALYSIS}

\subsection{Direction of Finite Strain}

In order to determine the direction of finite strain, the three principal strain axes $X, Y$, and $Z(X \geq Y \geq Z)$ should be determined. For this purpose, rock samples are cut parallel to the foliation which represents the plane of flattening (XY) and oriented perpendicular to $Z$. The maximum extension direction $\mathrm{X}$ is normal to the foliation and parallel to lineation (XZ). The intermediate strain direction $\mathrm{Y}$ is defined by its orthogonality with $\mathrm{X}$ and $\mathrm{Z}$, where it lies normal to foliation and lineation (YZ). The strain data confirm that the trends of the long axes of the finite strain ellipsoid (maximum extension direction, $\mathrm{X}$ axes) plunge gently to moderately towards the WNW-ESE (Fig. 4). In particular, the mean value for the long axes for all investigated samples displays WNW-ESE trend with a plunge of about $45^{\circ}$ (see Fig. 4 and Table 1). In addition, intermediate direction ( $\mathrm{Y}$ axes) exhibits ENE to WSW direction and a moderate angle of plunge (Fig. 4). The mean for all lithologies has ENE to WSW trend, and $29^{\circ}$ plunge, in addition to a subvertical attitude with respect to the $\mathrm{X}$ direction (Fig. 4). The maximum shortening direction (Z) plunges steeply towards the SES - NWN (Fig. 4), perpendicular to the subhorizontal foliation. Contouring of all collected data for $\mathrm{Z}$ axes reveals a maximum $174^{\circ} / 55^{\circ}$.

\subsection{Strain Symmetry}

The strain data are summarized in Tables $\mathbf{1}$ and $\mathbf{2}$ and shown in Flinn diagram (Fig. 5) which shows the relative shapes of the strain ellipsoids, i.e. prolate $v s$ oblate. According to [41], this classification is called strain symmetry. To infer strain type, i.e. constrictional $v s$ flattening, information on volume strain is needed. However, minor or no volume changes are expected in high grade rocks in which porosities during deformation were probably very small especially for the basement rocks [23]. Fig. (6a, b) display the $\mathrm{R}_{\mathrm{f}} / \varphi$ and Fry strains respectively, and indicate that Fry strains are not fundamentally different from $R_{f} / \varphi$ strains; the $\mathrm{R}_{\mathrm{f}} / \varphi$ strains are slightly smaller than the Fry strains. Therefore, the studied samples show that there was no significant difference in the deformation behavior between the quartz-mica matrix, the feldspar porphyroclasts and amphibole crystals during the accumulation of finite strain. Furthermore, finite strain of the different samples is of the same order of magnitude. The main phase foliation does not show any differences between the Abt schist, sheared granitoids and volcanosedimentary rocks, which also attest similarity in deformation behavior in the different rock types. The $R_{f} / \varphi$ strains derived from analyzing quartz and feldspar porphyroclasts and some mafic grains (hornblende and mica) are summarized in Table $\mathbf{2}$.

\subsection{Finite Stretches}

The strain ellipsoids have oblate strain symmetry (Fig. $5 \mathbf{a}, \mathbf{b})$. The axial ratios in the $\mathrm{XZ}$ sections range from 1.70 to 4.80 for the $\mathrm{R}_{\mathrm{f}} / \varphi$ method, and from 1.20 to 4.50 for the Fry method (Table 2). In addition, the $\mathrm{S}_{\mathrm{X}}$ averages range from 1.21 to 1.95 for the $\mathrm{R}_{\mathrm{f}} / \varphi$ method, and from 1.09 to 1.93 for the Fry method. The $S_{Y}$ ranges from 0.93 to 1.26 for the $R_{f} / \varphi$ method, and from 0.93 to 1.26 for the Fry method, showing contraction and extension in this direction. The stretches in the $\mathrm{Z}$ direction $\left(\mathrm{S}_{\mathrm{Z}}\right)$ range from 0.41 to 0.73 , indicating vertical shortening of $27 \%$ to $59 \%$ for the $\mathrm{R}_{\mathrm{f}} / \varphi$ method. Furthermore, the Fry strain data show that $S_{Z}$ varies from 0.25 to 0.91 , revealing vertical shortening of $9 \%$ to $75 \%$ (Table 2). The strain data illustrate no significant difference in the deformation behavior between the $R_{f} / \varphi$ and the Fry methods; Fry strain data support the results for $\mathrm{R}_{\mathrm{f}} / \varphi$ strain data. The data demonstrate also the same order of deformation in the various lithologies as detected in the field. The strain symmetry as expressed by the $\mathrm{K}$ value $[37,42]$ shows a moderate value ranging from 0.05 to 0.77 (Fig. 5). Accordingly, the strain symmetry is characterized by low to moderate oblate strain symmetries. The strain magnitudes of the investigated samples in Al Amar area have averages ranging from 0.397 to 1.145 , which indicate a very heterogeneous deformation (Table 2). The strain ellipsoids have oblate strain symmetry (Fig. 5). The strain symmetry shows a relationship between the tectonic contacts and deformation in the various lithologies in the study area. Additionally, the calculated $K$ values from $R_{f} / \varphi$ method for the Abt Schist and the volcanosedimentary samples are less than 1, referring to an oblate strain (Fig. 5). The $\mathrm{K}$ values decrease and show strong oblate strain symmetries toward the outer sides of the tectonic contacts between Abt Schist, sheared granitoids and volcanosedimentary rocks. The data 


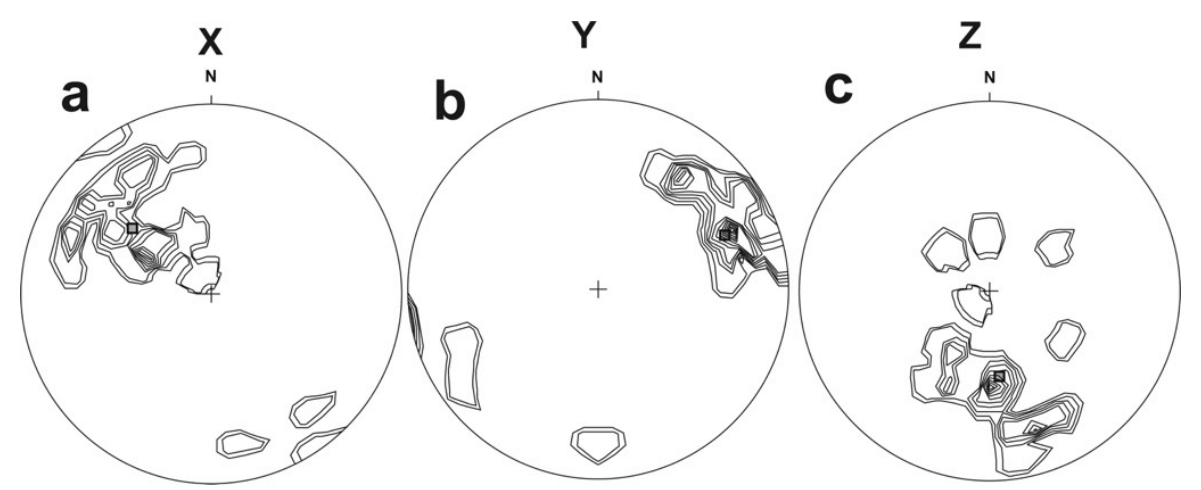

Fig. (4). Orientational data (lower hemisphere equal area projection): a) maximum extension direction (X), b) intermediate direction (Y); c) maximum shortening direction $(\mathrm{Z})$. Contours start at 3\% and increment every $3 \%$. Grey Squares in the stereographic projections represent mean values of tensor averages.

Table 1. Direction of Finite Strain Axes and Stretches for Samples from Al Amar Area

\begin{tabular}{|c|c|c|c|c|c|c|c|c|c|}
\hline \multirow{2}{*}{ Sample No. } & \multicolumn{3}{|c|}{$\mathbf{X}$} & \multicolumn{3}{|c|}{$\mathbf{Y}$} & \multicolumn{3}{|c|}{$\mathbf{Z}$} \\
\hline & Trend & Plunge & Stretch & Trend & Plunge & Stretch & Trend & Plunge & Stretch \\
\hline ALM2 & 333 & 29 & 1.16 & 84 & 32 & 1.03 & 212 & 43 & 0.84 \\
\hline ALM3 & 300 & 21 & 1.64 & 40 & 30 & 1.23 & 178 & 55 & 0.5 \\
\hline ALM5 & 140 & 20 & 1.91 & 235 & 13 & 1.36 & 357 & 67 & 0.38 \\
\hline ALM6 & 351 & 28 & 1.98 & 247 & 24 & 1.05 & 125 & 51 & 0.48 \\
\hline ALM7 & 320 & 30 & 2.05 & 70 & 30 & 0.94 & 195 & 46 & 0.52 \\
\hline ALM8 & 310 & 20 & 1.65 & 40 & 25 & 0.94 & 220 & 60 & 0.64 \\
\hline ALM12 & 300 & 40 & 1.62 & 65 & 30 & 1.21 & 180 & 40 & 0.51 \\
\hline AL 7 & 290 & 20 & 1.52 & 30 & 30 & 1.09 & 170 & 50 & 0.61 \\
\hline AL 8 & 290 & 55 & 1.45 & 50 & 20 & 1.03 & 150 & 25 & 0.67 \\
\hline AL 9 & 310 & 60 & 1.83 & 60 & 10 & 1.04 & 155 & 27 & 0.53 \\
\hline AL 10 & 330 & 80 & 1.46 & 80 & 3 & 1.09 & 170 & 10 & 0.63 \\
\hline AL 11 & 310 & 55 & 1.88 & 70 & 20 & 1.17 & 170 & 27 & 0.46 \\
\hline AL 12 & 340 & 62 & 1.91 & 78 & 5 & 1.03 & 170 & 25 & 0.51 \\
\hline Mean & 309 & 45 & & 67 & 29 & & 174 & 55 & \\
\hline
\end{tabular}

show no obvious relationship between the strain magnitude and the tectonic contacts in the area (Table 2).

\section{DISCUSSION}

\subsection{The Youngest Suturing Event in the ANS}

The evolution and tectonic setting of the ANS have attracted the attention of workers since the beginning of seventh decade of the last century, or probably older. At that time, the ANS was interpreted in terms of a single and complete Wilson Cycle, where a continental block rifted and fragmented into small blocks, drifted apart and new ocean basins being created, followed by a closing convergence phase $[6,2,43]$. In the mid-1980s, a new principal school of thought emerged where the ANS was regarded to comprise a collage of Neoproterozoic tectonic (or teconostratigraphic) terranes, separated by eye-catching structural elements, including major fault zones, high strain zones and original suture zones (ophiolite-decorated shear zones), as well as cryptic suture zones $[6,2,43]$. Within this framework, the ANS (and the entire EAO) was considered to be evolved by rifting of Rodinia (Rodinian) Supercontinent and creation of a Pacific-Sized Mozambique Ocean, closure of the resulting 
Table 2. Finite Strain Data for Sample from Al Amar Area

\begin{tabular}{|c|c|c|c|c|c|c|c|c|c|c|}
\hline \multirow{2}{*}{ Sample No. } & \multirow{2}{*}{ Method } & \multirow{2}{*}{ Rxy } & \multirow{2}{*}{ Ryz } & \multirow{2}{*}{$\mathbf{R x z}$} & \multicolumn{3}{|c|}{ Stretch } & \multirow{2}{*}{$\frac{\text { Principal Strain Ratios }}{\text { K }}$} & \multirow{2}{*}{$\frac{\text { Radius }}{\mathbf{r}}$} & \multirow{2}{*}{$\frac{\text { Strain Magnitude }}{\text { Et }}$} \\
\hline & & & & & $\mathbf{S x}$ & Sy & $\mathbf{S z}$ & & & \\
\hline \multirow{2}{*}{ ALM1 } & Rf/PHI & 1.05 & 1.07 & 1.12 & 1.05 & 1.01 & 0.94 & 0.67 & 1.12 & 0.081 \\
\hline & Fry & 1.16 & 1.65 & 1.91 & 1.3 & 1.13 & 0.68 & 0.24 & 1.81 & 0.480 \\
\hline \multirow{2}{*}{ ALM2 } & Rf/PHI & 1.13 & 1.23 & 1.39 & 1.16 & 1.03 & 0.84 & 0.57 & 1.36 & 0.235 \\
\hline & Fry & 1.2 & 1.38 & 1.65 & 1.25 & 1.05 & 0.76 & 0.51 & 1.58 & 0.359 \\
\hline \multirow{2}{*}{ ALM3 } & Rf/PHI & 1.33 & 2.49 & 3.3 & 1.64 & 1.23 & 0.50 & 0.22 & 2.82 & 0.883 \\
\hline & Fry & 1.37 & 2.19 & 3.01 & 1.61 & 1.17 & 0.55 & 0.31 & 2.56 & 0.802 \\
\hline \multirow{2}{*}{ ALM4 } & Rf/PHI & 1.35 & 2.58 & 3.49 & 1.68 & 1.24 & 0.48 & 0.22 & 2.93 & 0.922 \\
\hline & Fry & 1.29 & 1.88 & 2.43 & 1.46 & 1.13 & 0.60 & 0.33 & 2.17 & 0.646 \\
\hline \multirow{2}{*}{ ALM5 } & Rf/PHI & 1.40 & 3.56 & 4.99 & 1.91 & 1.36 & 0.38 & 0.16 & 3.96 & 1.199 \\
\hline & Fry & 1.37 & 1.95 & 2.67 & 1.54 & 1.13 & 0.58 & 0.39 & 2.32 & 0.709 \\
\hline \multirow{2}{*}{ ALM6 } & Rf/PHI & 1.89 & 2.19 & 4.13 & 1.98 & 1.05 & 0.48 & 0.74 & 3.08 & 1.005 \\
\hline & Fry & 1.38 & 1.68 & 2.32 & 1.47 & 1.07 & 0.64 & 0.56 & 2.06 & 0.600 \\
\hline \multirow{2}{*}{ ALM7 } & Rf/PHI & 2.18 & 1.82 & 3.96 & 2.05 & 0.94 & 0.52 & 1.43 & 3.00 & 0.976 \\
\hline & Fry & 1.88 & 1.67 & 3.14 & 1.81 & 0.96 & 0.58 & 1.31 & 2.55 & 0.811 \\
\hline \multirow{2}{*}{ ALM8 } & Rf/PHI & 2.42 & 1.71 & 4.14 & 2.16 & 0.89 & 0.52 & 2.00 & 3.13 & 1.015 \\
\hline & Fry & 1.75 & 1.46 & 2.56 & 1.65 & 0.94 & 0.64 & 1.64 & 2.21 & 0.669 \\
\hline \multirow{2}{*}{ ALM9 } & Rf/PHI & 1.16 & 1.03 & 1.19 & 1.11 & 0.96 & 0.93 & 5.18 & 1.19 & 0.132 \\
\hline & Fry & 1.52 & 1.4 & 2.13 & 1.48 & 0.97 & 0.69 & 1.3 & 1.92 & 0.536 \\
\hline \multirow{2}{*}{ ALM10 } & Rf/PHI & 1.21 & 1.23 & 1.49 & 1.22 & 1.01 & 0.82 & 0.92 & 1.44 & 0.282 \\
\hline & Fry & 1.38 & 1.49 & 2.06 & 1.42 & 1.03 & 0.69 & 0.78 & 1.87 & 0.512 \\
\hline \multirow{2}{*}{ ALM11 } & Rf/PHI & 1.47 & 2.25 & 3.31 & 1.09 & 1.15 & 0.51 & 0.38 & 2.72 & 0.864 \\
\hline & Fry & 1.19 & 1.95 & 2.32 & 1.40 & 1.18 & 0.60 & 0.20 & 2.14 & 0.628 \\
\hline \multirow{2}{*}{ ALM12 } & Rf/PHI & 1.34 & 2.38 & 3.19 & 1.62 & 1.21 & 0.51 & 0.25 & 2.72 & 0.853 \\
\hline & Fry & 1.21 & 2.38 & 2.89 & 1.52 & 1.25 & 0.53 & 0.16 & 2.59 & 0.799 \\
\hline \multirow{2}{*}{ AL 7} & Rf/PHI & 1.40 & 1.79 & 2.50 & 1.52 & 1.09 & 0.61 & 0.50 & 2.19 & 0.656 \\
\hline & Fry & 1.40 & 1.67 & 2.33 & 1.48 & 1.06 & 0.64 & 0.59 & 2.07 & 0.603 \\
\hline \multirow{2}{*}{ AL 8} & Rf/PHI & 1.41 & 1.53 & 2.15 & 1.45 & 1.03 & 0.67 & 0.76 & 1.94 & 0.542 \\
\hline & Fry & 1.32 & 1.39 & 1.83 & 1.43 & 1.02 & 0.73 & 0.81 & 1.71 & 0.428 \\
\hline \multirow{2}{*}{ AL 9} & Rf/PHI & 1.75 & 1.98 & 3.47 & 1.83 & 1.04 & 0.53 & 0.77 & 2.73 & 0.881 \\
\hline & Fry & 1.54 & 1.59 & 2.45 & 1.56 & 1.01 & 0.64 & 0.92 & 2.13 & 0.634 \\
\hline \multirow{2}{*}{ AL 10} & Rf/PHI & 1.33 & 1.74 & 2.32 & 1.46 & 1.09 & 0.63 & 0.45 & 2.07 & 0.605 \\
\hline & Fry & 1.17 & 1.86 & 2.18 & 1.37 & 1.17 & 0.63 & 0.20 & 2.03 & 0.582 \\
\hline I I & Rf/PHI & 1.61 & 2.56 & 4.13 & 1.88 & 1.17 & 0.46 & 0.39 & 3.17 & 1.020 \\
\hline AL II & Fry & 1.83 & 2.19 & 4.00 & 1.94 & 1.06 & 0.49 & 0.69 & 3.02 & 0.260 \\
\hline & Rf/PHI & 1.85 & 2.03 & 3.75 & 1.91 & 1.03 & 0.51 & 0.82 & 2.88 & 0.270 \\
\hline AL 12 & Fry & 1.83 & 1.95 & 3.57 & 1.87 & 1.02 & 0.52 & 0.87 & 2.78 & 0.900 \\
\hline
\end{tabular}



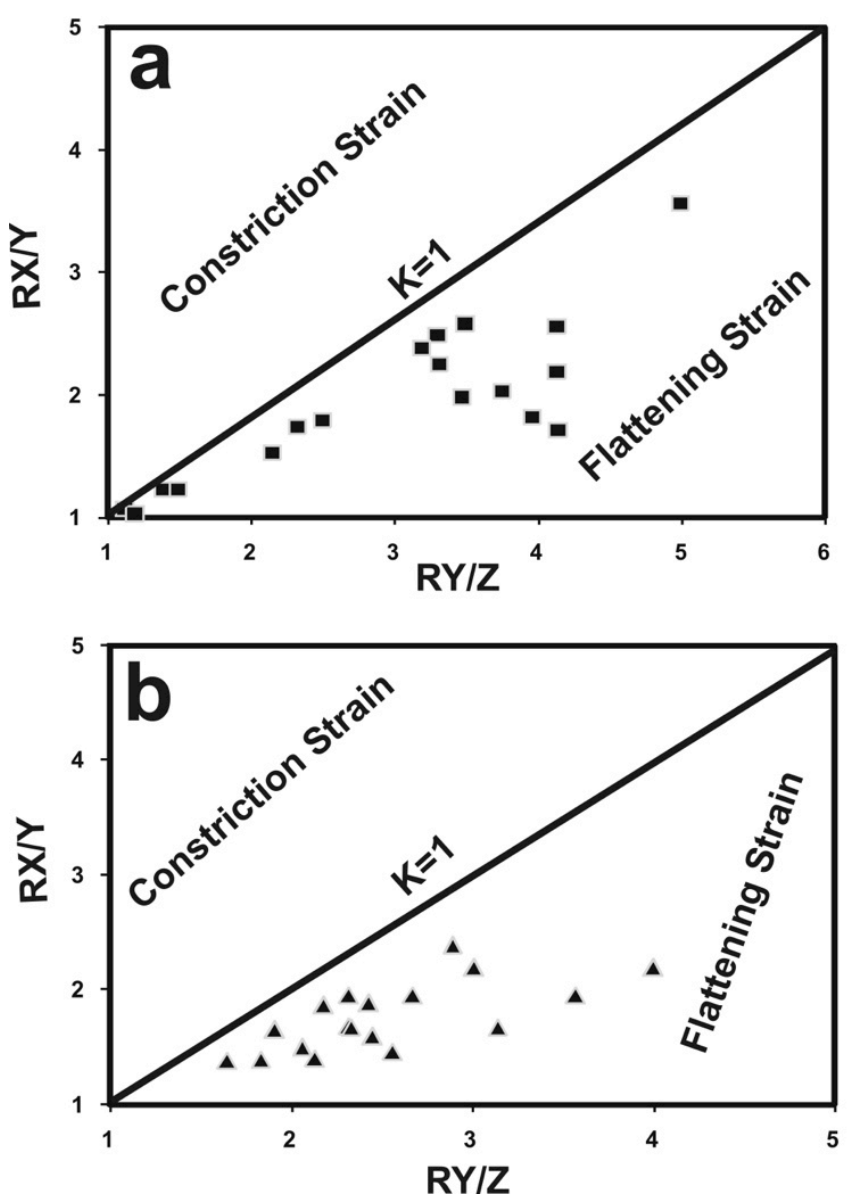

Fig. (5). Flinn diagram [16] showing relative strain or strain symmetry as obtained by (a) the $\mathrm{R}_{\mathrm{f}} / \varphi$ method (b) the Fry method. $R_{f} / \varphi$ strain data are shown by black squares and Fry strain data are shown by black triangle from the same samples.

ocean, arc assembly or accretionary, orogeny, extension and orogenic collapse $[2,6,9,43,44]$. In spite of the general agreement about the ANS terrane concept by most researchers, distinctive geology, petrological, geochemical and deformational characteristics of the proposed terranes are matters of dimensions and still controversial. Besides terrane boundaries, whether some mega shears and high strain zones represent original sutures or not, kinematic evolution, and timing of suturing are also debatable and enigmatic subjects. As previously mentioned in an earlier section, the youngest terranes in the ANS are believed to be Ad Dawadimi and Ar Rayn terranes in the far east of the Arabian Shield. Lithologically, Ad Dawadimi terrane includes immature sediments of Abt Formation (Abt Schist), syenogranite and alkali-feldspar granite, together with small outcrops of fresh younger gabbros (with remarkable layering) and minor lenses of ophiolitic metaultramafics [45, 46]; the ophiolitic mélange shows forearc affinity [7]. Ar Rayn terrane embraces arc volcanics and related volcaniclastics, in addition to voluminous calk-alkaline plutonic rocks and minor sedimentary outcrops belonging to Al Amar Group [47]. The unique geographic situation of Ad Dawadimi terrane led some authors [48] to affiliate it to an outboard micro-continent encompassing also Ar Rayn terrane, and others $[49,50]$ to consider it as a back-arc basin separating Afif and Ar Rayn terranes. However, both Ad
Dawadimi and Ar Rayn terranes are in direct juxtaposition along the westward steeply dipping N-directed Al Amar Suture. This Suture transects volcanosedimentary and associated plutonic rocks of Al Amar arc (689-583 Ma), sedimentary rocks of Abt Formation $(\geq 620 \mathrm{Ma})$ and sedimentary and volcanic rocks of Hamir Group (615-605 $\mathrm{Ma}$ ), and the timing of suturing is inferred to occur between $\sim 620-605 \mathrm{Ma}$, making the suture to represent the youngest one in the ANS [20]. These authors (op.cit.) supposed that both terranes are important because: "(1) they are the youngest terranes in the ANS, with upper Cryogenian to Ediacaran protoliths; (2) they provide evidence for subduction in the Ediacaran, well after other terranes had already amalgamated; (3) their mutual juxtaposition represents the youngest suturing event in the ANS; and (4) their juxtaposition with terranes to the west reflects the final closure of the Mozambique Ocean and the convergence of Neoproterozoic India with the African continents". Moreover, [9] came to the conclusion that Ad Dawadimi Terrane is an Ediacaran basin representing the youngest accretion event of the exposed ANS, and therefore the timing of events within the basin is key to understanding both the closure of the Mozambique Ocean and the amalgamation of Gondwana along the northern EAO.

\subsection{Kinematic Evolution of Al Amar Suture}

Major shear zones and sutures in the ANS have caught much more attention since the last decade in terms of kinematic evolution and deformation history. A growing number of structural papers have described in details the shear sense indicators $[51,52]$ and others applied finite strain- and kinematic vorticity-techniques for porphyroclasts in mylonitized rocks transected by shearing [25-29]. Given the importance of Al Amar Suture as the youngest terrane boundary in the whole ANS and its significance in unraveling the closure of the Mozambique Ocean and the final assembly of Gondwana, we selected an area along the contact between Ad Dawadimi and Ar Rayn terranes. This area is bounded by the latitude of Umm Ash Shalahib in the south and the latitude of Khnaiguiyah in the north, and could be easily accessible through Ar Riyadh-Jeddah asphaltic road. It is studied in some structural details in terms of field structural mapping, lithologic discrimination and deformational history, with special emphasis to the kinematic evolution. The exposed lithologies in the mapped area are shown in Fig. (2). The mean for all examined samples shows ENE to WSW trend and $29^{\circ}$ plunge, in addition to a subvertical attitude with respect to the $X$ direction. The Z-axes plunge steeply towards NWN-SES, normal to the subhorizontal foliation. Although, the $R_{f} / \varphi$ strains are slightly smaller than the Fry strains, the strain data show no significant differences in the deformation behavior between $\mathrm{R}_{\mathrm{f}} / \varphi$ and Fry methods; similarity in order of deformation in the studied lithologies is well observed in the field. These strains show similarity in deformation behavior between quartz-mica matrix, feldspar porphyroclasts and mafic crystals in the investigated samples during the accumulation of finite strain which was not associated with any significant volume change and this consequently indicate that finite strain in the different rock varieties has the same order of magnitude. The penetrative S- 
surfaces (foliation planes), particularly in Abt Schist, have nearly the same attitudes of tectonic contacts with the overlying nappes and are believed to be contemporaneous with thrusting in the study area. The obtained finite strain data conflict the suggestion that nappes in orogens resulted from simple-shear deformation.

\section{CONCLUSIONS}

Based on finite stain data from the high-angle $\mathrm{N}$-directed Al Amar Suture, the youngest accretion event in the entire ANS, we came to the following concluding remarks:-

- The strain ellipsoids have oblate strain symmetry.

- There is no significant difference in the deformation behavior between $R_{f} / \varphi$ and Fry methods in the investigated lithologies.

- Accumulation of finite strain in the area was not accompanied by significant volume change.

- The finite strain in various lithologies has the same order of magnitude.

- The obtained finite strain data conflict the suggestion that nappes in orogens resulted from simple-shear deformation.

\section{CONFLICT OF INTEREST}

The authors confirm that this article content has no conflict of interest.

\section{ACKNOWLEDGEMENTS}

The authors would like to extend their sincere appreciation to the Deanship of Scientific Research at King Saud University for its funding of this research through the Research Group project no RGP-VPP-230. We thank journal reviewers for critical and helpful comments and for editorial handling.

\section{REFERENCES}

[1] Johnson PR, Halverson GP, Kusky TM, Stern RJ, Pease V. Volcanosedimentary basins in the Arabian-Nubian shield :Markers of repeated exhumation and denudation in a Neoproterozoic Accretionary Orogen. Geosciences 2013; 3: 389-445.

[2] Stern RJ. Crustal evolution in the East African Orogen: a neodymium isotopic perspective. J Afr Earth Sci 2002; 34: 109-17.

[3] Stern RJ, Johnson PR. Continental lithosphere of the Arabian Plate: a geologic, petrologic, and geophysical synthesis. Ear-Sci Rev 2010; 101: 29-67.

[4] Worsley TR, Nance RD, Moody JB. Tectonic cycles and the history of the Earth's biogeochemical and paleoceanographic record. Paleogeography 1986; 1: 233-63.

[5] Meert JG, Torsvik TH. The making and unmaking of a supercontinent: Rodinia revisited. Tectonophys 2003; 375: 261-88.

[6] Stern RJ. Arc assembly and continental collision in the Neoproterozoic East African Orogen: implications for the consolidation of Gondwanaland. Ann Rev Plan Sci 1994; 22: 31519.

[7] Collins AS, Pisarevsky SA. Amalgamating eastern Gondwana: the evolution of the Circum-Indian Orogens. Ear Sci Rev 2005; 71: 229-70.

[8] Dalziel IWD. Neoproterozoic-Paleozoic geography and tectonics: review, hypothesis, environmental speculation. Geolog Soc Am Bull 1997; 109(1): 16-42.
[9] Cox GM, Lewis CJ, Collins AS, et al. Ediacaran terrane accretion within the Arabian-Nubian Shield. Gondwana Res 2012; 341-52.

[10] Muhongo S. Neoproterozoic collision tectonics in the Mozambique Belt of East Africa; evidence from the Uluguru Mountains, Tanzania. J Afr Earth Sci 1994; 19: 153-68.

[11] Muhongo S, Lenoir JL. Pan-African granulite-facies metamorphism in the Mozambique Belt of Tanzania; U-Pb zircon geochronology. Geol Soc Lond 1994; 151: 343-47.

[12] Fritz H, Tenczer V, Hauzenberger CA, et al. Central Tanzanian tectonic map: a step forward to decipher Proterozoic structural events in the East African Orogen. Tectonics 2005; 24(6): 1-15.

[13] Fritz H, Tenczer V, Hauzenberger CA, Wallbrecher E, Muhongo S Hot granulite nappes-Tectonic styles and thermal evolution of the Proterozoic granulite belts in East Africa. Tectonophys 2009; 477: 160-73.

[14] Viola G, Henderson IHC, Bingen B, Thomas RJ, Smethurst MA, de Azavedo S. Growth and collapse of a deeply eroded orogen: insights from structural, geophysical, and geochronological constraints on the Pan-African evolution of NE Mozambique. Tectonics 2008; 27(5): 1-19.

[15] Jacobs J, Thomas RJ. Himalayan-type indenter-escape tectonics model for the southern part of the late Neoproterozoic-early Paleozoic East African-Antarctic Orogen. Geology 2004; 32: 72124.

[16] Collins AS, Windley BF. The Tectonic Evolution of central and northern Madagascar and its place in the final assembly of Gondwana. J Geol 2002; 110: 325-40.

[17] Cawood PA, Kroner A, Collins WJ, Kusky TM, Mooney WD, Windley BF. Accretionary Orogens through Earth History. J Geol Soc Lond, Spec Publ 2009; 318: 1-36.

[18] Fritz H, Abdelsalam M, Ali KA. Orogen styles in the East African Orogen: A review of the Neoproterozoic to Cambrian tectonic evolution. J Afr Earth Sci 2013; 86: 65-106.

[19] Coolen JJM, Priem HNA, Verdurmen EAT, Verschure RH. Possible zircon U-Pb evidence of Pan-African granuilite facies metamorphism in the Mozambique belt of southern Tanzania. Precamb Res 1982; 17: 31-40.

[20] Johnson P, Andresen A, Collins AS, Fowler TR, Fritz H, Ghebreab W, Kusky T. Late Cryogenian-Ediacaran history of the ArabianNubian Shield: A review of depositional, plutonic, structural, and tectonic events in the closing stages of the northern East African Orogen. J Afr Earth Sci 2011; 61: 167-232.

[21] Greenwood WR, Anderson RE, Fleck RJ, Roberts RJ. Precambrian Geologic History and Plate Tectonic Evolution of the Arabian Shield. Saudi Arabian Directorate General of Mineral Resources Bulletin 1980; 24: 35.

[22] Berhe SM. Ophiolites in NE and east Africa: implications for Proterozoic crustal growth. J Geol Soc Lond 1990; 147: 41-57.

[23] Kassem OMK, Ring U. Underplating-related finite-strain patterns in the Gran Paradiso massif, Western Alps, Italy: heterogeneous ductile strain superimposed on a nappe stack. Geol Soc Lond 2004; 161: 875-84.

[24] Ring U, Kassem OMK. The nappe rule: why does it work? Geol Soc Lond 2007; 164: 1109-12.

[25] Kassem OMK, Raheim AS. Finite strain analysis for the Metavolcanic-sedimentary rocks in the Gabel El- Mayet region, Central Eastern Desert, Egypt. J Afr Earth Sci 2010; 58: 321-30.

[26] Kassem OMK. Determining Heterogeneous deformation for Granitic rocks in the Northern thrust in Wadi Mubark belt, Eastern Desert, Egypt. Geotectonics J 2011; 45(3): 244-54.

[27] Kassem OMK. Kinematic Vorticity Technique for Porphyroclasts in the Metamorphic Rocks: An Example from the Northern thrust in Wadi Mubarak belt, Eastern Desert, Egypt. Arab J Geosci 2012; 5 (1): 159-67.

[28] Kassem OMK, Abd El Rahim SH, El Nashar ER. Strain analysis and Microstructural evolution characteristic of Neoproterozoic rocks associations of Wadi El Falek, Centre Eastern Desert, Egypt. Geotectonics J 2012; 46(5): 379-88.

[29] Al-Saleh AM, Kassem OMK. Microstructural, Strain Analysis and ${ }^{40} \mathrm{Ar} /{ }^{39} \mathrm{Ar}$ Evidence for the Origin of the Mizil Gneiss Dome, Eastern Arabian Shield, Saudi Arabia. J Afr Earth Sci 2012; 70: 2435.

[30] Bailey EH, Irwin WP, Jones DL. Franciscan and related rocks, and their significance in the geology of western California. California Div Mines Bull 1964; 183: 177. 
[31] Berkland JO, Ray LA. What is Franciscan? Am Assoc Petro Geol Bull 1972; 56.

[32] Ferrand A, Milesi P, Prevot C. Geologic and metallogenic assessment of the Al Amar Deposit, Deputy Miuistry For Mineral Resources, Jiddah, Kingdom of Saudi Arabia 1985.

[33] Al-Shanti AMS, Mitchell AHG. Late Precambrian subduction and collision in the Al Amar-Idsas region, Kingdom of Saudi Arabia. Tectonophys 1976; 30: T41-T47.

[34] Nawab ZAH. Evolution of the Al Amar Idasas region of the northern part of the Arabian Shield (Kingdom of Saudi Arabia). Bull du BRGM (deuxieme series) 1978; 1-19, sec II, no 1-2.

[35] Fry N. Random point distributions and strain measurement in rocks. Tectonophysics 1979; 60: 89-105.

[36] Ramsay JG. Folding and Fracturing of rocks, McGraw Hill, London 1967.

[37] Ramsay JG, Huber MI. The Techniques of Modern Structural Geology, volume 1: Strain Analysis. Academic Press: New York 1983.

[38] Peach CJ, Lisle RJ. A fortran IV program for the analysis of tectonic strain using deformed elliptical markers. Comp Geosci 1979; 5: 325-34.

[39] Passchier CW, Trouw RAJ. Microtectonics. 2nd ed. Springer, Berlin 2005; p. 289.

[40] Owens WH. The calculation of a best-fit ellipsoid from elliptical sections on arbitrarily oriented planes. J Stru Geol 1984; 6: 571-78.

[41] Hossack JR. Pebble deformation and thrusting in the Bygdin area (Southern Norway). Tectonophys 1968; 5: 315-39.

[42] Flinn D. On folding during three-dimensional progressive deformation. Quarternary. J Geol Soc Lond 1962; 118: 385-433.

[43] Johnson PR, Woldehaimanot B. Development of the ArabianNubian shield: perspectives on accretion and deformation in the northern East African Orogen and the assembly of Gondwana. In: Yoshida, M, Windley, BF, Dasgupta, S, (Eds.), Proterozoic East Gondwana: Supercontinent Assembly and Breakup: J Geol Soc Lond, Spec Publ 2003; 206: 290-325.
[44] Greiling RO, De Wall H , Kontny A, Kober B, El Hinnawi M, Sadek MF, Abdeen MM. Pan-African orogeny in the ArabianNubian shield: convergence, escape, and collapse. J Afr Earth Sci, 2000; 30: 36 .

[45] Al-Shanti AMS. Mineralization of Ad Dawadimi District, Kingdom of Saudi Arabia. Saudi Arabian Directorate General of Mineral Resources Bulletin 1976; 14: 50.

[46] Kennedy A, Kozdroj W, Kattan FH, Kodzroj MZ, Johnson PR. SHRIMP Geochronology in the Arabian Shield (Midyan Terrane, Afif Terrane, Ad Dawadimi Terrane) and Nubian Shield (Central Eastern Desert), Part IV. Data Acquisition 2008. Saudi Geological Survey Open-File Report SGS-OF-2010-10, 2010; 101

[47] Johnson PR, Stewart ICF. Magnetically inferred basement structure in central Saudi Arabia. Tectonophysics 1995; 245: 37-52.

[48] Stoeser DB, Camp E. Pan-African microplate accretion of the Arabian shield. Geol Soc Am Bull 1985; 96: 817-26.

[49] Al-Saleh AM, Boyle AP. Structural rejuvenation of the eastern Arabian Sshield during continental collision: $40 \mathrm{Ar} / 39 \mathrm{Ar}$ evidence from the Ar Ridaniyah ophiolite mélange. J Afr Earth Sci 2001; 33: $135-41$.

[50] Doebrich JL, Al-Jehani AM, Siddiqui AA, et al. A Geology and metallogeny of the Ara Rayn terrane, eastern Arabain shield. Evolution of a Neoproterozoic continental-margin arc during assembly of Gondwana within the East African Orogen. Precam Res 2007; 158: 17-50.

[51] Hamimi Z, El-Sawy KE, El-Fakharani A, Shujoon A, Matsah M, El-Shafei M. Neoproterozoic Structural Evolution of the NEtrending 620-540 Ma Ad-Damm Shear Zone, Arabian Shield, Saudi Arabia. J Afr Earth Sci, Spec Issue (S. El-Gaby) (in press) 2013.

[52] Hamimi Z, El-Shafei M, Kattu G, Matsah M. Transpressional Regime in Southern Arabian Shield: Insights from Wadi Yiba Area, Saudi Arabia. Gondwana Collision (Especial issue, Mineralogy and Petrology), (in press); 2012.

(C) Zhang et al.; Licensee Bentham Open.

This is an open access article licensed under the terms of the Creative Commons Attribution Non-Commercial License (http://creativecommons.org/licenses/by$\mathrm{nc} / 3.0 /$ ) which permits unrestricted, non-commercial use, distribution and reproduction in any medium, provided the work is properly cited. 